\title{
Foraminifera as environmental proxies of the Middle Miocene (Early Badenian) sediments of the Central Depression (Central Paratethys, Moravian part of the Carpathian Foredeep)
}

\author{
JITKA KOPECKÁ
}

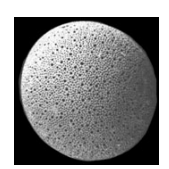

\begin{abstract}
Middle Miocene sediments of the Central Depression have been studied based on foraminifera with a view to characterize palaeoenvironmental conditions. Rock material from HV-5 Rybníček core were used. Foraminiferal evidence indicates biostratigraphic range of the lower part of the Upper Lagenid Zone (Early Badenian-Langhian, Middle Miocene). The sediments originate from a deeper marine basin at the level of outer shelf with potential extension deeper into the bathyal realm. Bottom waters were well-oxygenated with a redox boundary a few centimeters from the sea floor which was colonized by sub- and dysoxic foraminifers. Palaeotemperature of marine water corresponds to the Miocene climatic optimum with short-time climatic oscillations of cooler climate. $\bullet$ Key words: Middle Miocene, Early Badenian, Central Paratethys, Carpathian Foredeep, foraminifera, palaeoecology, Czech Republic.
\end{abstract}

KOPECKÁ, J. 2012. Foraminifera as environmental proxies of the Middle Miocene (Early Badenian) sediments of the Central Depression (Central Paratethys, Moravian part of the Carpathian Foredeep). Bulletin of Geosciences 87(3), 431-442 (7 figures, 2 tables, appendix). Czech Geological Survey, Prague, ISSN 1214-1119. Manuscript received July 7, 2011; accepted in revised form January 13, 2012; published online June 12, 2012; issued September 28, 2012.

Jitka Kopecká, Department of Biology, Faculty of Education, Palacký University, Purkrabská 2, 77146 Olomouc, Czech Republic; jitka.kopecka@upol.cz.

The Carpathian Foredeep was a large intracontinental sea consisting of a chain of basins extending through the Alpine-Carpathian region and exhibits striking lateral changes in basin width, depth, stratigraphy and sedimentary infill, along with variations in pre-Neogene basement composition and tectonic subsidence (e.g. Kováč 2000). The basins were frequently connected with the Mediterranean, the Indo-Pacific and the Atlantic, but periodically also isolated (Rögl \& Steininger 1983, Rögl 1998, Popov et al. 2004).

The Badenian Carpathian Foredeep was a peripheral foreland basin in the northwest Central Paratethys developed at the European plate margin due to Carpathian accretionary wedge overthrusting and deep subsurface loading (e.g. Kováč et al. 2007, Nehyba \& Šikula 2007). The Early Badenian transgression occurred in the Central Paratethys in two phases (Hohenegger et al. 2009). The first phase is documented by planktonic foraminiferal assemblages with Praeorbulina sicana and P. glomerosa within the NN4 calcareous nannoplankton Zone around 16.3-16.2 Ma (Rögl et al. 2002). The sea flooding crossed the Dinarides via Slovenia and northern Croatia (Transtethyan Trench Corridor) reaching the Pannonian
Basin system (Popov et al. 2004). The second Early Badenian transgression was characterized by dominant planktonic assemblages with $P$. glomerosa circularis and Orbulina suturalis within the calcareous nannoplankton NN5 Zone around 14.7 Ma (Rögl et al. 2002). This transgressive event widened the North West Croatian Basin, Vienna Basin, Danube Basin, East Slovak Basin and Transylvanian Basin and reached also the Carpathian Foredeep (Kováč et al. 2007).

The Early Badenian sedimentation in the Carpathian Foredeep began with deposition of conglomerates containing reworked Early Miocene mollusks, which pass upward into a series of claystones and sandstones (Papp et al. 1978). The basal levels are overlain by pelitic sediments (grey-green calcareous clays, so called "tegels") with sandstone intercalations and biohermal bodies (Cicha \& Čtyroká 1995, Cicha 2001). The morphology of the basin changed to a grabenlike structure with the deepest part above $400 \mathrm{~m}$ in the center of basin (Brzobohatý 1997, Nehyba et al. 2000). The third-order depositional sequence was recognized for the Early Badenian deposits, which was dominated by both eustacy and tectonics (Nehyba \& Sikula 2007) 


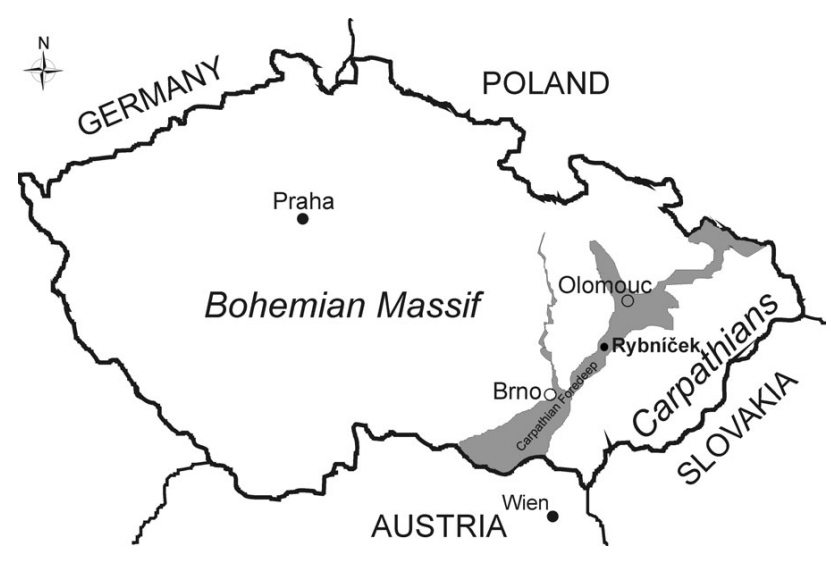

Figure 1. Position of the HV-5 Rybníček core in the Moravian part of the Carpathian Foredeep.

The Central Depression is an axial part of the Carpathian Foredeep (Czech Republic) and the analyzed area is situated in its middle part (Fig. 1). In previous studies of the locality, Molčíková (1963), Burghard \& Molčíková (1964), and Kopecká (2009) have presented the foraminiferal fauna and the age of deposits was interpreted as Early Badenian (Kopecká 2009).

This paper focuses on the foraminifera-rich Badenian deposits in the Moravian part of the Carpathian Foredeep. Its aim is to interpret palaeoenvironmental conditions during the Early Badenian based on detailed sampling of the deposits and quantitative processing of the foraminifers.

\section{Material and methods}

The rock material from the HV-5 Rybníček core was studied. Because the rock material has degraded over time (the core was drilled in 1962), the lithological characteristics are presented based on the data from the e-Earth application (the core database, Czech Geological Survey, available at: https://www.geofond.cz/mapsphere/EEARTH/default.aspx ?lang=cs). Individual strata of the core had a massive character without clear separating of overlying and underlying strata. There were recognized lithofacies of light greygreen calcareous clays and calcareous clays with sandy or gravel intraclasts. Some parts of the core contained shell fragments and volcanic glass (Fig. 2).

The core material was sampled at approximately $1 \mathrm{me}-$ ter intervals. Foraminifers in all the samples were picked from $63 \mu \mathrm{m}-2 \mathrm{~mm}$ fractions after washing disintegrated rock samples in water. For palaeoecological analyses, seventy samples were processed and from each sample 200-300 specimens of foraminifera were identified to species level.

Foraminiferal fauna were classified to the benthic and planktonic foraminiferal clusters using Ward's method and Euclidean distance.
Palaeoecological analysis was based on following data:

(1) Palaeodepth, which was estimated in terms of the relationship between bathymetry and relative abundance of planktonic foraminifera as determined by Van der Zwaan et al. (1990):

$$
\mathrm{D}(\mathrm{m})=\mathrm{e}^{3.58718+(0.03534 \times \mathrm{Pc})}
$$

where D is estimated depth in meters, e is Euler's number and $\mathrm{Pc}$ is corrected ratio of planktonic/benthic foraminifera and it is calculated according the formula:

$$
\mathrm{Pc}=(\mathrm{P} \times 100) /[\mathrm{P}+(\mathrm{Bt}-\mathrm{Bi})],
$$

where $\mathrm{P}$ is the number of planktonic foraminifera, $\mathrm{Bt}$ is total number of benthic foraminifera and $\mathrm{Bi}$ is the number of deep infaunal species as stress markers after Van der Zwaan (1990), Van Hinsbergen et al. (2005) and Báldi (2006), which are excluded from analysis because they are not directly dependent on the flux of organic matter to the sea floor. The reliability of the calculated palaeodepth can be biased by observation that the plankton/benthos ratio ( $\mathrm{P} / \mathrm{B}$ - ratio) is not only influenced by depth, but also by changes in oxygenation of bottom waters (Sen-Gupta \& Machain-Castillo 1993, Jorissen et al. 1995). Discrepancy between calculated palaeodepth and sedimentology has been pointed out e.g. for the Middle Miocene of the Central Paratethys (Hohenegger 2005). Therefore, estimation of palaeodepth using modified plankton/benthos - ratio was compared with depth ranges of individual benthic taxa (e.g. Murray 1991, Rögl \& Spezzaferri 2003, Hohenegger 2005, van Hinsbergen et al. 2005).

(2) Benthic Foraminiferal Oxygen Index (BFOI), which was interpreted by Kaiho $(1994,1999)$ and was used to estimate oxygen content. It was calculated according the equation:

$$
\text { BFOI }(\%)=\mathrm{O} /(\mathrm{O}+\mathrm{D}) \times 100,
$$

where $\mathrm{O}$ is the number of oxic indicators and $\mathrm{D}$ is the number of disoxic indicators. These indicators were classified according to Kaiho (1994, 1999), Den Dulk et al. (2000), Spezzaferri et al. (2002) and Báldi (2006).

(3) Palaeotemperature changes in the upper layer of the water column, which were estimated based on the ratio among cool- and warm-water species of planktonic foraminifera (Spezzaferri \& Ćorić 2001, Spezzaferri et al. 2002, Bicchi et al. 2003).

\section{Results}

\section{Characteristics of the foraminiferal assemblages}

One hundred and fifty two benthic and 24 planktonic species were identified. Well-preserved foraminiferal tests 
Jitka Kopecká • Foraminifera as environmental proxies of the Middle Miocene sediments of the Central Depression

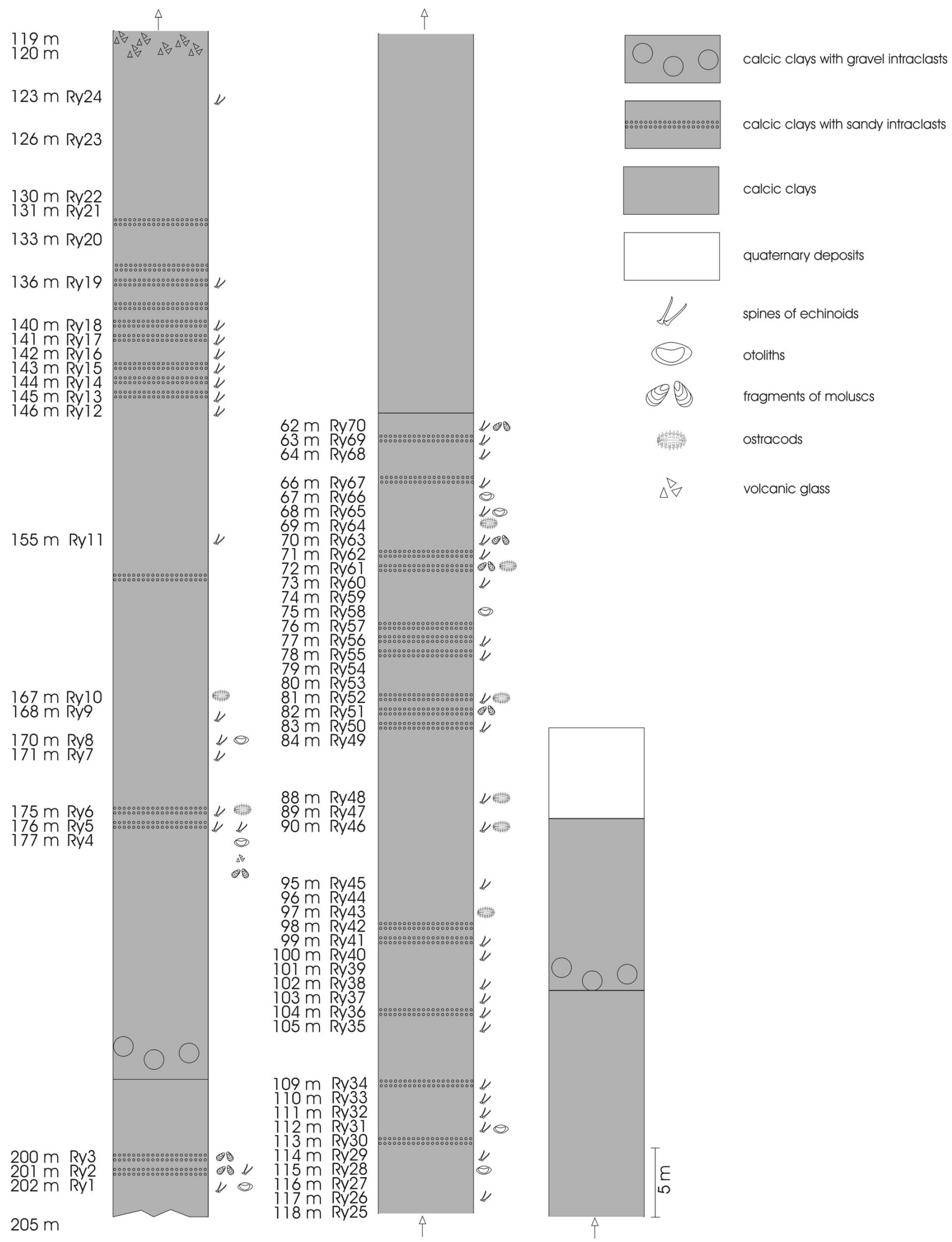

Figure 2. Lithology and location of sampling points for the HV-5 Rybníček core. 


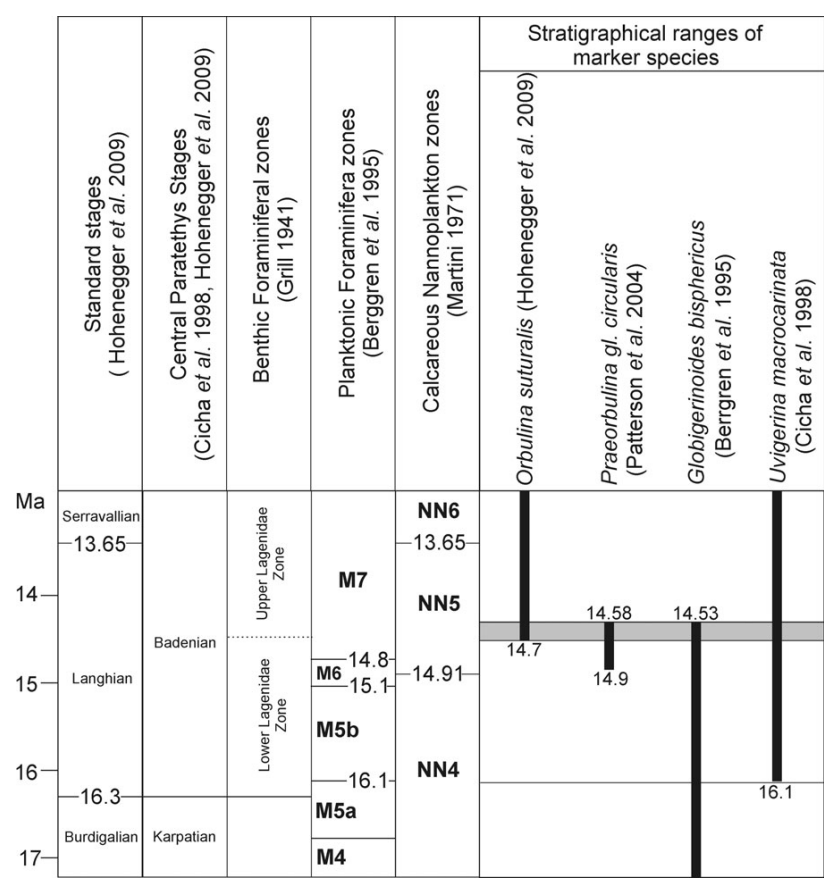

Figure 3. Biostratigraphical correlation and stratigraphical ranges of marker species from the HV-5 Rybníček core.

without evidence of abrasion and corrosion, no size sorting and occurrence of both adults and juvenile individuals indicate that the assemblages are not markedly taphonomically changed.

Assemblages are generally abundant and diverse, plankton/benthos ratios vary from 30 to $90 \%$ in the samples. The benthic assemblages are characterized by good mature individuals and dominated by the following genera: Uvigerina, Bulimina, Cibicidoides, Melonis, Neugeborina and Stilostomella. Assemblages of planktonic foraminifers are characterized small tests of individuals and by occurrence of Globigerinoides trilobus, G. bisphericus, Globigerina praebulloides, G. bulloides, Globorotalia bykovae, Gl. transsylvanica, Paragloborotalia mayeri, Praeorbulina glomerosa circularis and Orbulina suturalis.

\section{Biostratigraphy}

HV-5 Rybníček sections can be correlated with the planktonic foraminiferal standard global zonation (Berggren et al. 1995) as well as Paratethyan zonations (Rögl 1986, Cicha et al. 1998, Harzhauser \& Piller 2007, Piller et al. 2007). Correlation (Fig. 3) was based on the co-occurrence of planktonic foraminiferal species Orbulina suturalis, Praeorbulina glomerosa circularis and Globigerinoides bisphericus and thus this section can be correlated with the lower part of the "upper lagenid zone" (Middle Miocene, Badenian; Grill 1941, Papp \& Turnovsky 1953, Hohenegger et al. 2009).

\section{Palaeoecological and statistical indices}

\section{Benthic foraminifera}

Benthic foraminiferal fauna were grouped into seven distinct assemblages using cluster analysis (Fig. 4A). All of the assemblages are characterized by relatively high occurrences of high productivity indicators, mainly sub- and dysoxic species. The Cibicidoides-Melonis cluster, represents a group of samples with a marked mixture of oxiphylic (mainly Cibicidoides) and sub-/dysoxic (mainly Melonis) taxa. The proxies are sumarized in Table 1.

1. The Uvigerina cluster groups seven samples with a relative abundance of benthic infauna of $31-53 \%$. The Shannon-Weaver index of diversity within this cluster ranges from 2.8-3.3; the Jaccard index of equitability has values of $0.8-0.9$. P/B-ratio varies from $37-56 \%$. The calculated palaeodepth based on the modified P/B-ratio is at the interval of 428 to $617 \mathrm{~m}$ (Fig. 5B) and the estimated palaeodepth based on depth ranges of benthic foraminifera is more than $150 \mathrm{~m}$ (Fig. 5A). Values of BFOI range from 19-53 (low to high oxic environment) (Fig. 6A).

2. The Bulimina cluster groups 15 samples with suboxic and agglutinated foraminifers. The cluster can be divided into a "Martinottiella-Bulimina" subcluster with

Table 1. Proxies of benthic foraminifera grouping in the clusters.

\begin{tabular}{|c|c|c|c|c|c|c|c|c|}
\hline Cluster & $\begin{array}{l}\text { Number } \\
\text { of } \\
\text { samples }\end{array}$ & $\begin{array}{l}\text { Plankton/ } \\
\text { benthos } \\
\text { ratio }(\%)\end{array}$ & $\begin{array}{c}\text { Relative } \\
\text { abundance of } \\
\text { sub-/ disoxic } \\
\text { indicators }(\%)\end{array}$ & $\begin{array}{c}\text { Relative } \\
\text { abundance of } \\
\text { shallow water } \\
\text { indicators }(\%)\end{array}$ & $\begin{array}{c}\text { Shannon- } \\
\text { Weaver } \\
\text { diversity index } \\
(\mathrm{H})\end{array}$ & $\begin{array}{c}\text { Index of } \\
\text { equitability }(\mathrm{J})\end{array}$ & $\begin{array}{c}\text { Estimated } \\
\text { palaeodepth (m) } \\
\text { after Van der } \\
\text { Zwaan (1990) }\end{array}$ & $\begin{array}{l}\text { Estimated palaeodepth } \\
\text { after Hohenegger } \\
\text { (2006) and Rögl \& } \\
\text { Spezzaferri (2003) }\end{array}$ \\
\hline Uvigerina & 7 & $51-72$ & $31-53$ & $2.8-3.3$ & $0.8-0.9$ & $428-617$ & $>150$ & $19-53$ \\
\hline Bulimina & 15 & $61-77$ & $11-20$ & $2.7-3.5$ & 0.9 & $467-618$ & $100-150$ & $6-75$ \\
\hline Praeglobobulimina & 8 & $73-86$ & $31-38$ & $2.6-3.0$ & 0.9 & $589-878$ & $>150$ & $41-63$ \\
\hline Cibicidoides-Melonis & 14 & $65-87$ & $12-40$ & $2.6-3.4$ & 0.9 & $496-888$ & $>100$ & $22-75$ \\
\hline Neugeborina & 8 & $55-62$ & $38-60$ & $2.3-3.3$ & $0.8-0.9$ & $260-449$ & $>100$ & $12-61$ \\
\hline $\begin{array}{l}\text { Neugeborina- } \\
\text { Stilostomella }\end{array}$ & 4 & $55-62$ & $42-59$ & $2.5-3.0$ & 0.9 & $315-325$ & $>200$ & $44-79$ \\
\hline Melonis & 14 & $59-76$ & $25-79$ & $2.6-3.3$ & $0.8-0.9$ & $378-627$ & $>200$ & $30-90$ \\
\hline
\end{tabular}


Jitka Kopecká • Foraminifera as environmental proxies of the Middle Miocene sediments of the Central Depression
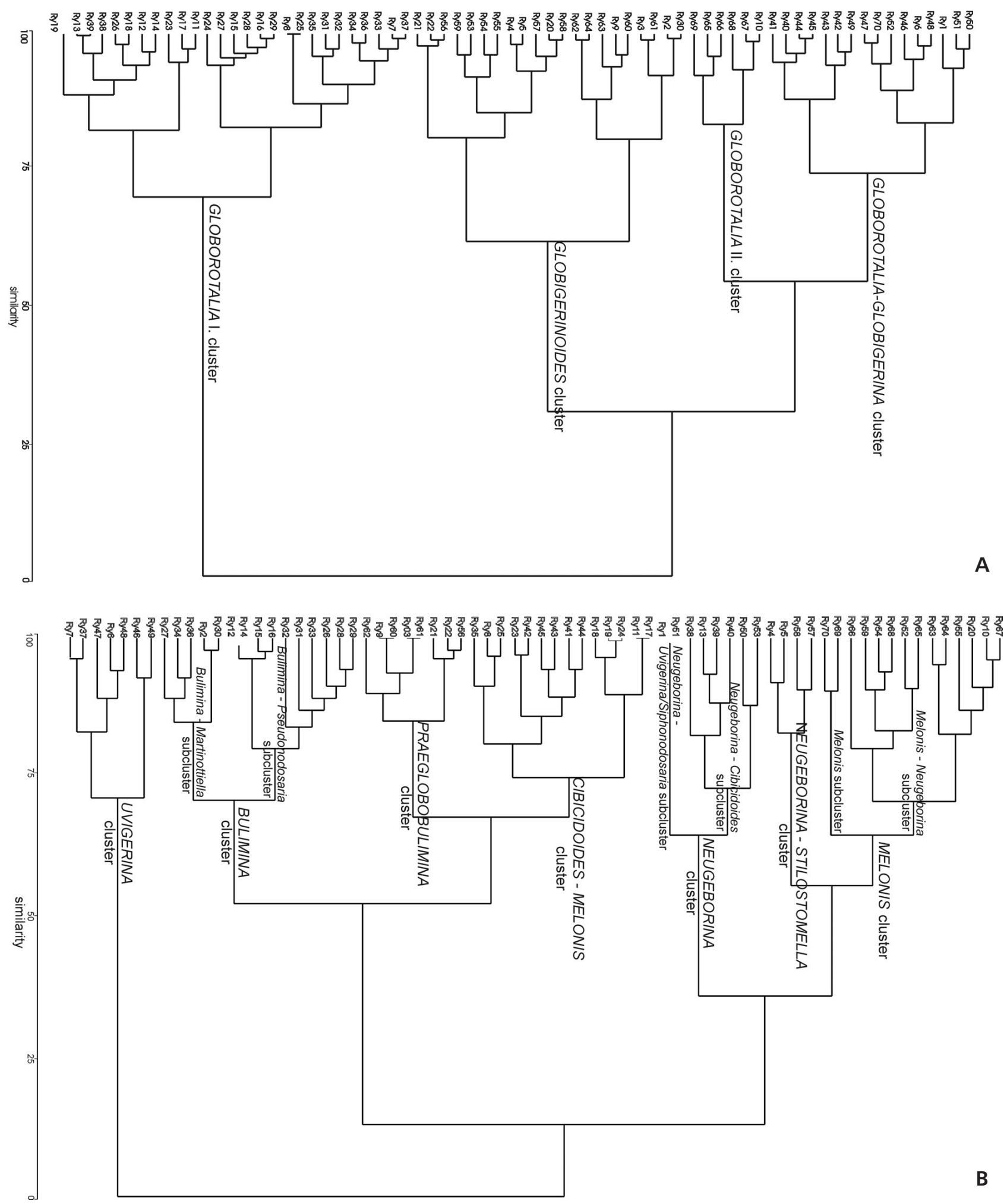

Figure 4. Hierarchical tree obtained by cluster analysis using Ward's method and Euclidean distance for: A - benthic foraminifera, B - planktonic foraminifera. 
13-20\% of sub-/dysoxic species and 5-9\% of agglutinated species and a "Pseudonodosaria-Bulimina" subcluster with $11-19 \%$ of sub-/dysoxic species and $1-6 \%$ of agglutinated species.

In the cluster, the Shannon-Weaver index of diversity values range from 2.7 to 3.5 ; the Jaccard index of equitability has values of 0.9 in all the samples. P/B-ratios vary from 44 to $62 \%$; BFOI values vary widely from 6 to 75 (low to high oxic environment) (Fig. 6A). The calculated palaeodepth varies from 467 to $618 \mathrm{~m}$ (Fig. 5A) and the estimated palaeodepth is between 100-150 m (Fig. 5B).

3. The Praeglobobulimina cluster groups eight samples including three samples (Ry9, Ry21 and Ry60) with relatively high relative abundance of benthic infauna (31-38\%). The Shannon-Weaver index of diversity values range from 2.6-3.0; the Jaccard index of equitability is 0.9 for all the samples; P/B-ratios vary from 57 to $74 \%$. BFOI values of 41-63 (medium to high oxic conditions) are seen in this cluster (Fig. 6A). Calculated palaeodepths vary from $589-878 \mathrm{~m}$ and the estimated palaeodepth is more than $150 \mathrm{~m}$ (Fig. 5A, B).

4. The Cibicidoides-Melonis cluster groups fourteen samples with sub-/disoxic (12-40\%) foraminifers and agglutinated (2-16\%) foraminifers mixed with a high occurence of oxiphylic foraminifers (7-34\%). The Shannon-Weaver index of diversity values range from 2.6-3.4; Jaccard index of equitability is 0.9 and the $\mathrm{P} / \mathrm{B}$-ratio varies from 48 to $72 \%$. BFOI is at the interval of 22-75 (low to high oxic conditions) (Fig. 6A). Calculated palaeodepth for these samples varies from $496-888 \mathrm{~m}$ and the estimated palaeodepth is more than $100 \mathrm{~m}$ (Fig. 5A, B).

5. The Neugeborina cluster groups eight samples with dominant species Neugeborina longiscata (d'Orbigny) and abundant sub-/dysoxic and agglutinated foraminifers. Shannon-Weaver index of diversity values are at the interval of 2.3-3.3 and the Jaccard index of equitability is $0.8-0.9$; P/B-ratio varies from 30 to $49 \%$. The cluster can be divided to two subclusters: a Uvigerina/Siphonodosaria subcluster and a Cibicidoides subcluster. The Uvigerina/Siphonodosaria subcluster is characterized by $60 \%$ sub-/dysoxic species (with high abundances of Uvigerina and Siphonodosaria) and $11 \%$ of agglutinated species (with high abundances of Martinottiella). The Cibicidoides subcluster is characterized by a mixture of sub-/dysoxic species (38-60\%) with dominant Uvigerina and Bulimina, oxiphylic species (3-17\%) with dominant Cibicidoides and agglutinated species (1-10\%) with dominant Martinottiella.

In the cluster, BFOI reached values from 12 to 61 (low to high oxic environment) (Fig. 6A). The calculated palaeodepth varies from 260 to $449 \mathrm{~m}$ and the estimated palaeodepth is more than $100 \mathrm{~m}$ (Fig. 5A, B).

6. The Neugeborina/Stilostomella cluster groups four samples and is characterized by the presence of suboxic species (42-59\%) and agglutinated forminifers, mainly Martinottiella karreri (5-9\%) with a co-occurence of Heterolepa dutemplei (2-15\%). Values for the Shannon-weaver index of diversity varies from 2.5 to 3.0 ; the Jaccard index of equitability has value of 0.9 ; P/B-ratio is $38-39 \%$ and BFOI values in the range of 44-79 (medium to high oxic). The calculated palaeodepth varies from $315-325 \mathrm{~m}$ and the estimated palaeodepth is more than $200 \mathrm{~m}$.

7. The Melonis cluster groups fourteen samples with a high occurrence of sub-/dysoxic species (25-79\%, with the following dominant genera: Melonis, Stilostomella and Bulimina) and agglutinated species (6-17\%, with dominant Martinottiella) and can be characterized by Shannon-Weaver index of diversity values of 2.6 to 3.3, Jaccard index of equitability with values of 0.8 to 0.9 and P/B-ratio with values of 44 to $61 \%$. BFOI values are in the range of 30 to $90 \%$ (medium to high oxic conditions) (Fig. 6A). Calculated palaeodepth varies from 378 to $627 \mathrm{~m}$ and the estimated palaeodepth is more than $200 \mathrm{~m}$ (Fig 5A, B).

\section{Planktonic foraminifera}

The ecological preferences of planktonic foraminifera are herein retained following Spezzaferri et al. (2002) and Bicchi et al. (2003). The present Globigerina (except G. diplostoma) and Turborotalia are considered coolwaters indicators; Globorotalia and Globoturborotalia are considered cool-temperate waters indicators. Praeorbulina-Orbulina, Globigerinoides, Paragloborotalia, Globoquadrina altispira and Globigerina diplostoma are considered warm-water indicators and Paragloborotalia mayeri considered warm-temperate water indicators.

Planktonic foraminiferal fauna were grouped, using Ward's method of cluster analysis, into four assemblages (A-D) (Fig. 4B). The proxies are summarized in Table 2.

A. The Globorotalia I. cluster groups 27 samples and is characterized by the dominant Globorotalia group (39-79\%) in association with the Globigerina group (3-23\%), the Globigerinodes group (3-36\%) and the Paragloborotalia group (5-11\%). The ratio between cooland warm-water indicators varies from 43 to $88 \%$ (Fig. 7A). Shannon-Weaver index of diversity values vary from 1.4 to 2.3 and the Jaccard index of equitability has values of $0.6-0.9$.

B. The Globigerinoides cluster groups 19 samples and is characterized by dominant Globigerinoides group (5-53\%) with Globorotalia group (12-40\%), Globigerina group (5-22\%) and Praeorbulina/Orbulina group (2-49\%). The ratio between cool- and warm-water indicators varies from 18 to $57 \%$ (Fig. 7A). Shannon-Weaver index of diversity values vary from 1.3 to 2.3 and Jaccard index of equitability has values of 0.6-0.9.

C. The Globorotalia II. cluster is small and groups only six samples. Predominant Globorotalia group (51-73\%) 
A

\section{Uvigerina cluster}

Uvigerina acuminata

Uvigerina macrocarinata

Uvigerina grilli

Cibicidoides ungerianus

Melonis pompiloides

Bulimina striata

Laevidentalina elegans

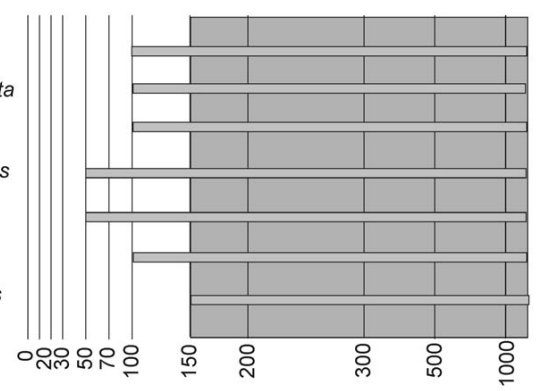

\section{Bulimina cluster}

Bulimina striata

Uvigerina semiornata

Uvigerina acuminata

Lenticulina gr.

Valvulineria complanata

Praeglobobulimina gr

Globulina gibba

Sigmoilinita tenuis

Asterigerinata planorbis

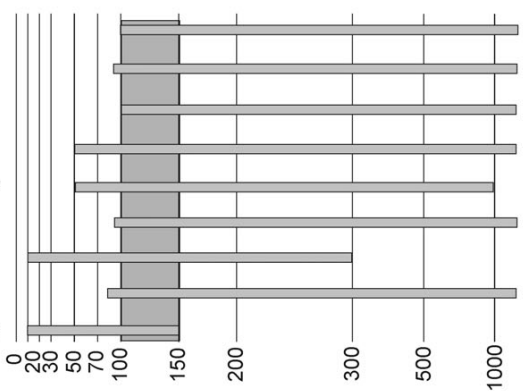

Praeglobobulimina cluster

Praeglobobulimina gr. Laevidentalina elegans Cibicidoides ungerianus Heterolepa dutemplei Uvigerina acuminata Bulimina striata Lenticulina gr.

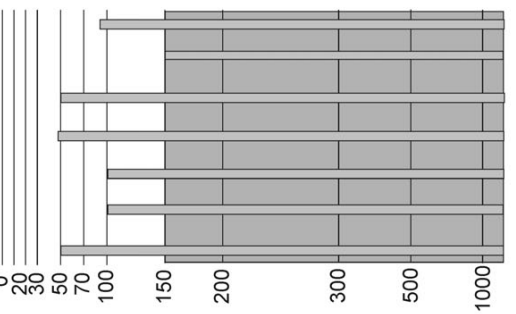

\section{Cibicidoides-Melonis cluster}

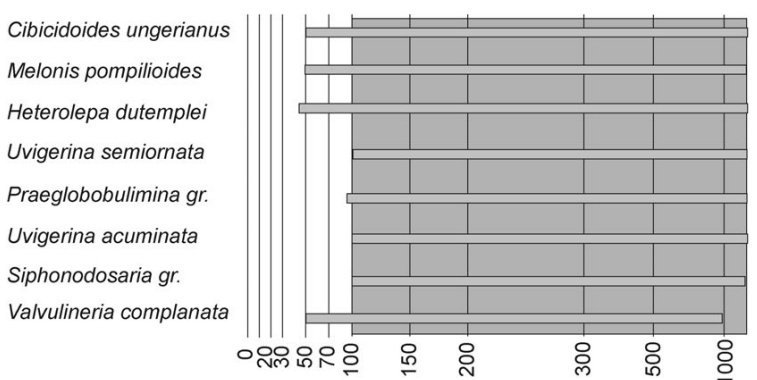

\section{Neugeborina cluster}

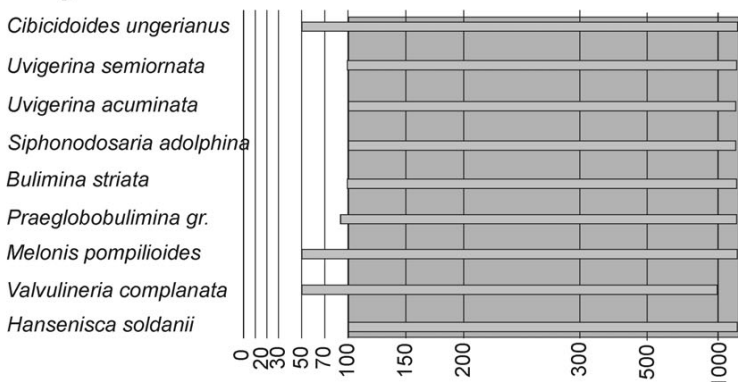

\section{Neugeborina-Stilostomella cluster}

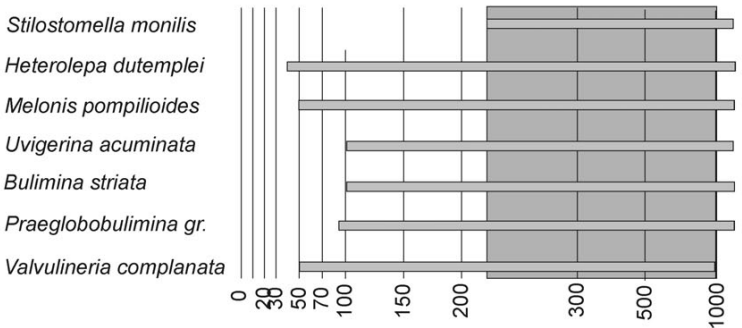

\section{Melonis cluster}

Melonis pompilioides Cibicidoides ungerianus Stilostomella monilis Bulimina striata Laevidentalina elegans Bolivina dilatata Heterolepa dutemplei Valvulineria complanata Nonion commune

B
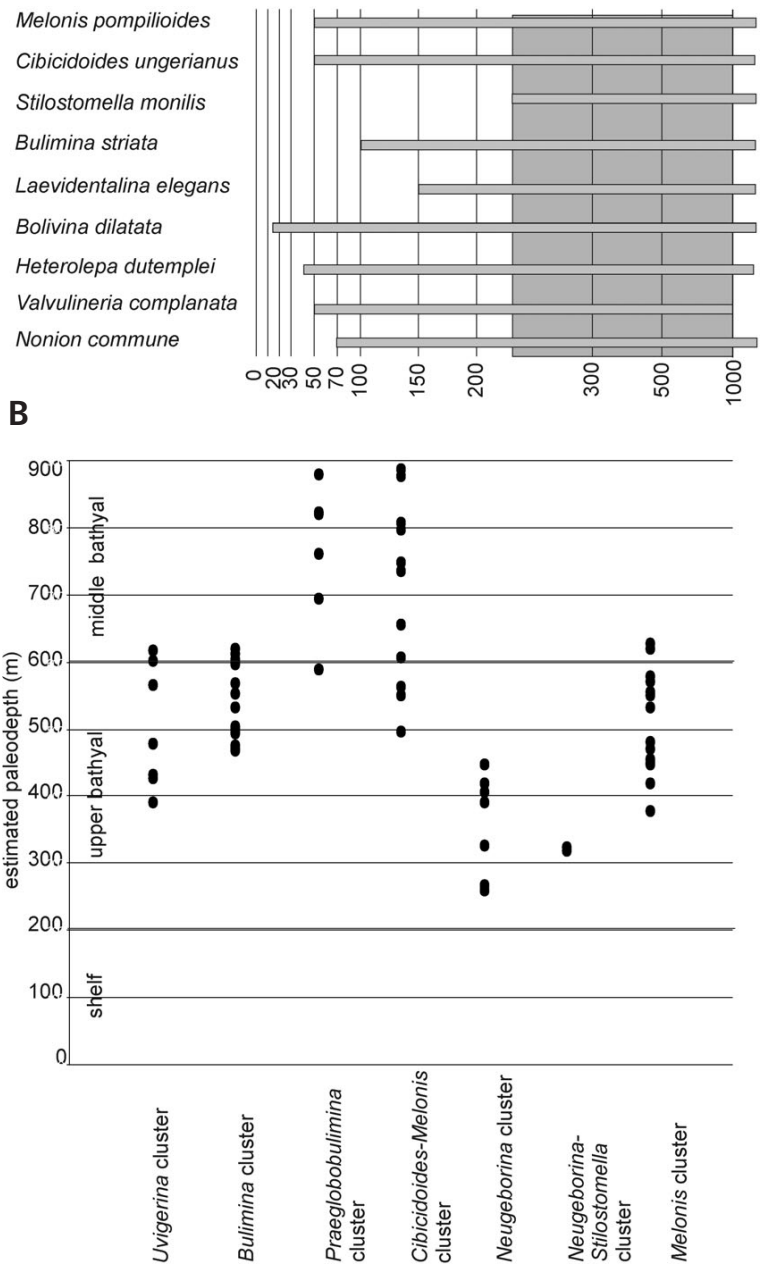

Figure 5. Palaeodepth estimation for benthic foraminiferal clusters. $\bullet$ A - estimated palaeodepth based on depth ranges of benthic foraminifera. $\cdot \mathrm{B}$ - estimated palaeodepth based on modified P/B-ratio. 


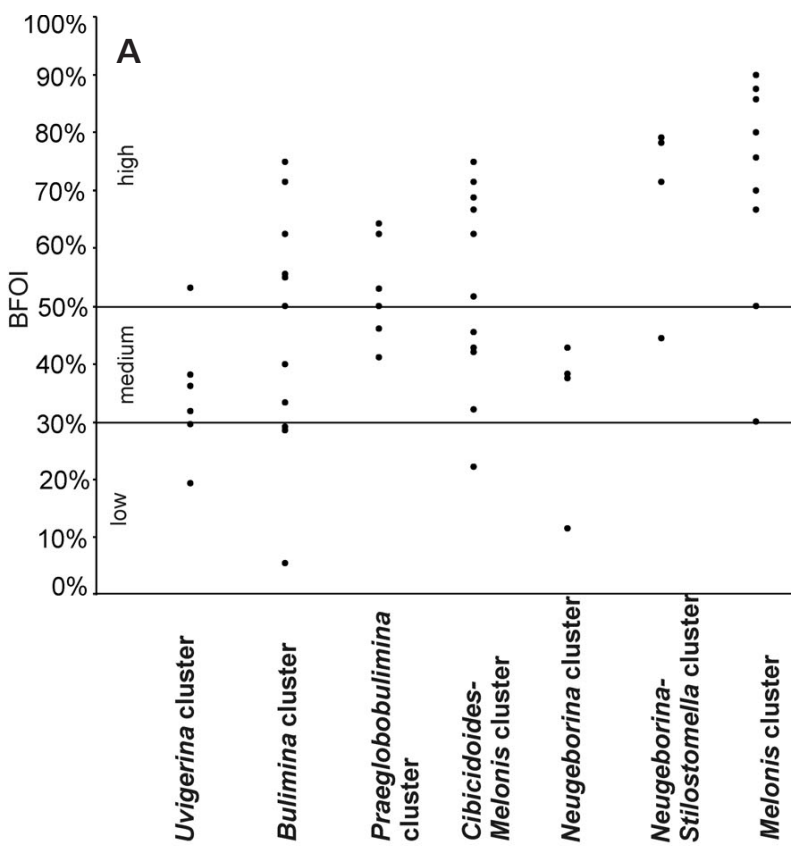

B

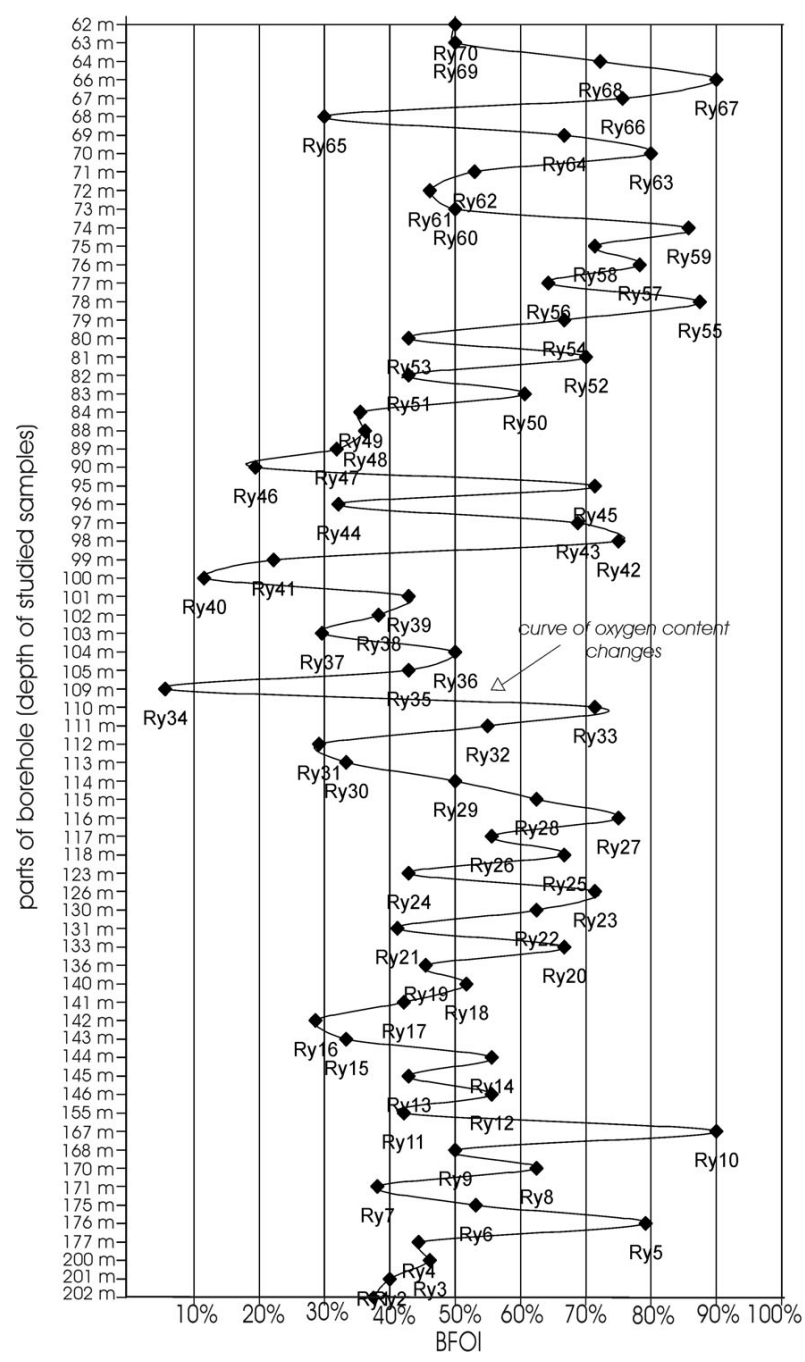

and high values of the ratio between cool- and warm-water indicators (68-84\%) characterize this cluster (Fig. 7A). Shannon-Weaver index of diversity values vary from 1.3 to 2.3 and Jaccard index of equitability has values of 0.6-0.9.

D. The Globorotalia-Globigerina cluster groups 18 samples with Globorotalia group (15-52\%) and Globigerina group (3-43\%), Paragloborotalia group (2-38\%) and Globigerinoides group (4-35\%). The ratio between cool- and warm-water indicators varies from 32 to $75 \%$ (Fig. 7A); the Shannon-Weaver index of diversity reaches values of 1.7-2.3 and the Jaccard index of equitability reaches values of $0.7-0.9$.

\section{Discussion}

\section{Benthic foraminiferal assemblages and their proxies}

Benthic foraminiferal fauna have relatively low values of diversity (Shannon-Weaver index in range of 2.3-3.5), high values of equitability (Jaccard index in range of 0.8-0.9) and high occurrence of high productivity markers (infauna) in assemblages.

\section{Oxygen content}

A common feature of all assemblages is a relatively high occurence (12-79\%) of high primary productivity markers (infaunal taxa) (Den Dulk et al. 2000), which are dysoxic and suboxic indicators (Kaiho 1999) - mainly Bulimina striata, B. schischinskayae, Melonis pompilioides, Praeglobobulimina pyrula, P. pupoides, Fursenkoina acuta, Uvigerina macrocarinata, U. grilli, U. uniseriata.

The sub- and dysoxic foraminifers are mixed with oxiphylic epifaunal species (mainly cibicidoids). This mixture of sub-/dysoxic and oxiphylic species is typical of dead foraminiferal assemblages from muddy environments. The palaeoenvironment was characterized by wellaerated bottom water with a redox boundary a few centimeters from the see floor which was colonized by sub- and disoxic foraminifers (Murray 2001). Number of dead foraminiferal assemblages and their decomposition had an effect on the oxygen content at the sea floor.

Changes in oxygen content are evident from the values of BFOI (Fig. 6A). Low to medium oxygen content is characterized by the Uvigerina cluster and Neugeborina cluster, low to high oxygen content) by the Bulimina cluster and the Cibicidoides-Melonis cluster and medium to high

Figure 6. Benthic Foraminiferal Oxygen Index (BFOI). $\bullet$ A - BFOI-marker of oxygen content in the assemblages of the benthic clusters. - B - changes of the oxygen content along the core. 
oxygen content for the Praeglobobulimina cluster, the Neugeborina-Stilostomella cluster and the Melonis cluster. In the core, values of BFOI reflect periodic changes in oxygen content, mainly from medium to high. In the middle part of the profile (depth of 109-99 m), there is significant decrease in BFOI values (changes between low and medium oxygen content; Fig. 6B).

Relatively high occurence of benthic infauna and common occurence of oxyphylic species in the samples point to decrease of oxygen levels caused by decomposition using up oxygen at the sea floor, not to total sub- or disoxic environment. It supports also by occurrence of good mature benthic foraminifera as on of indicators of good oxygen conditions and by small individuals of planktonic foraminifera as one of indicators of eutrophization.

\section{Estimated palaeodepth}

Palaeowater depth estimates are based on two different proxies, independent of each other (Van der Zwaan et al. 1990, Hohenegger 2005). The proxy of Van der Zwaan et al. (1990) is based on modified P/B-ratio, while the proxy of Hohenegger (2005) is based on depth ranges of recent benthic foraminifera.

Both proxies showed palaeodepth conditions at the level of outer shelf to bathyal. Estimated palaeodepth based on modified P/B-ratio showed a deep-water condition with an estimated palaeodepth in the range of 260-888 $m$ which probably reflects limited validity of the equation generated by Van der Zwaan et al. (1990) in the suboxic conditions (Jorissen et al. 1995). Palaeodepth estimated from the bathymetric ranges showed palaeodepth conditions of outer shelf zone (Bulimina cluster, 100-150 m), outer shelf to bathyal zone (Uvigerina cluster, Cibicidoides-Melonis cluster, Neugeborina cluster) with estimated palaeodepth in the range of $100 \mathrm{~m}$ and deeper, and the bathyal zone (Praeglobobulimina cluster, Neugeborina-Stilostomella cluster and Melonis cluster) with estimated palaeodepths of $230 \mathrm{~m}$ and deeper (Fig. 5A).

Because the applied $\mathrm{P} / \mathrm{B}$ ratio method is sensitive to eutrophy causing high productivity surface water and oxygen deficiency at the bottom culling benthic life (Van der Zwann et al. 1990), the calculated palaeodepth can be overestimated. It is evident from the Bulimina cluster with the occurrence of shallow water marker Asterigerinata planorbis where the calculated palaeodepth based on $\mathrm{P} / \mathrm{B}$-ratio is in the range of $467-618 \mathrm{~m}$ but the palaeodepth based on depth ranges varies from 100-150 m. On the other

Figure 7. Palaeotemperature indices in the upper layer of the water column. $\cdot$ A - ratio of cool-water and warm-water indicators in the assemblages of the planktonic clusters. $\cdot \mathrm{B}$ - changes of the ratio of cool-water and warm-water indicators along the core.

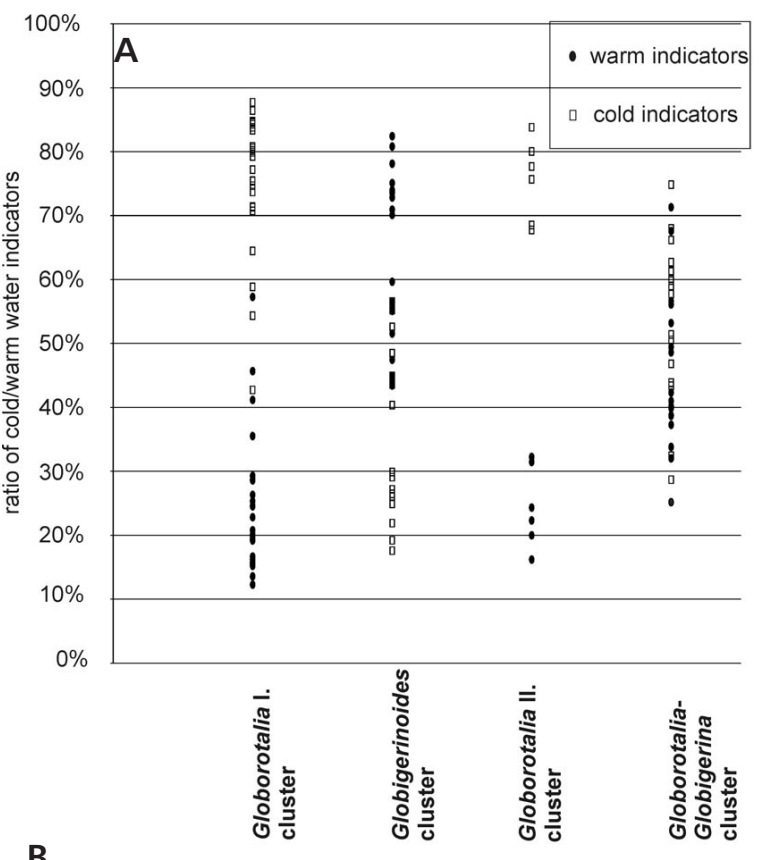

B

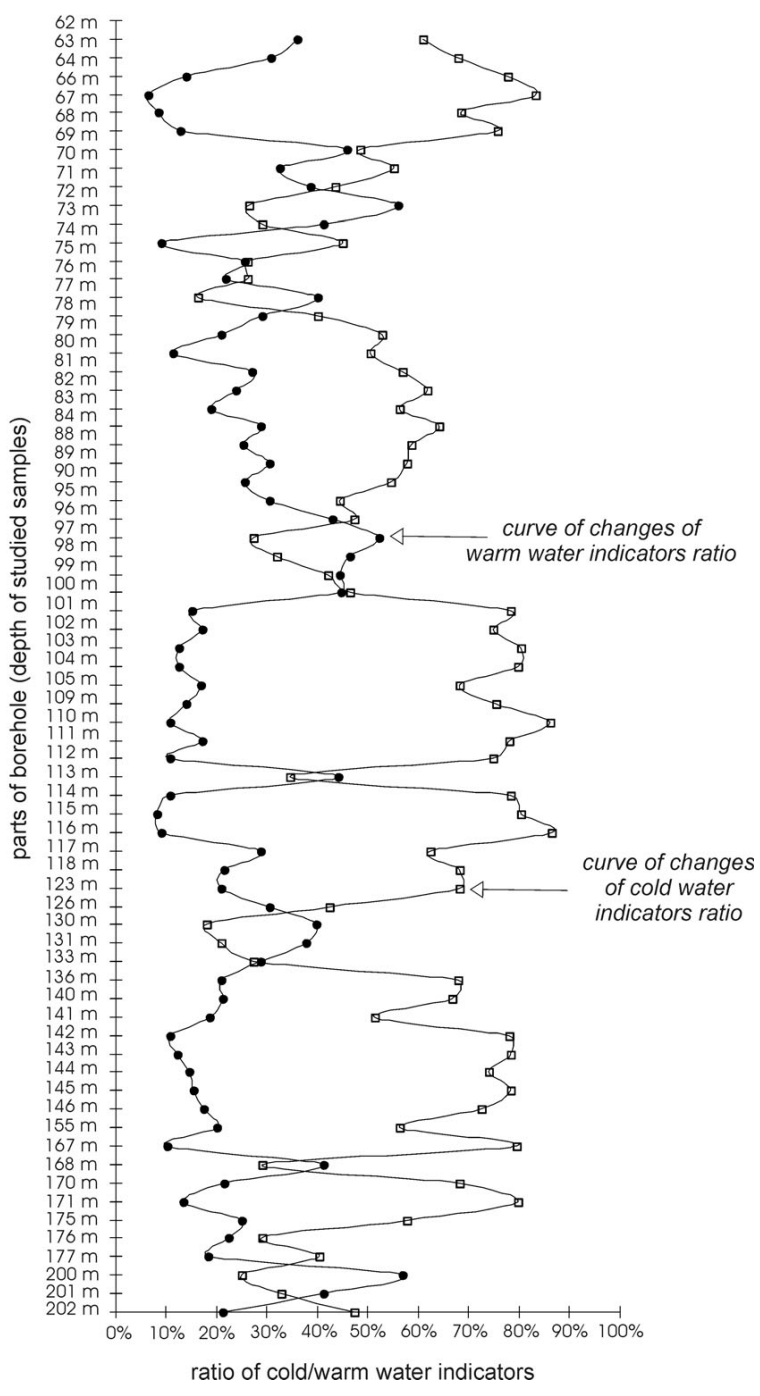


Table 2. Proxies of planktonic foraminifera grouping in the clusters.

\begin{tabular}{|c|c|c|c|c|}
\hline Cluster & Number of samples & Shannon-Weaver diversity index $(\mathrm{H})$ & Index of equitability $(\mathrm{J})$ & Cold/warm indicators ratio \\
\hline Globorotalia I. & 27 & $1.4-2.3$ & $0.6-0.9$ & $43-88$ \\
\hline Globigerinoides & 19 & $1.3-2.3$ & $0.6-0.9$ & $18-57$ \\
\hline Globorotalia II. & 6 & $1.3-2.3$ & $0.6-0.9$ & $68-84$ \\
\hline Globorotalia-Globigerina & 18 & $1.7-2.3$ & $0.7-0.9$ & $32-75$ \\
\hline
\end{tabular}

hand, the Neugeborina-Stilostomella cluster and the Melonis cluster with the occurrence of Stilostomella monilis, which prefers a depth range of more than $200 \mathrm{~m}$ (Rögl \& Spezzaferri 2003), and the co-occurrence of planktonic deep water element Globorotalia bykovae (Hilbrecht in Rupp \& Hohenegger 2008, Itou et al. in Rupp \& Hohenegger 2008) suggest, that palaeowater depth could extend from the level of shelf to bathyal. Bathyal deep water conditions in the HV-5 Rybníček core and at the other localities in the Moravian part of the Carpathian Foredeep (Hrušovany nad Jevišovkou, Brno-Královo Pole, Myslejovice, Drahanovice) have been described also by Brzobohatý $(1981,1997)$ based on an occurrence of a great number of mictophid otoliths indicating depths below 400 m (Brzobohatý 1997).

\section{Planktonic foraminifera and palaeotemperature water indices}

Planktonic foraminiferal assemblages are characterized by very low values and fluctuations of diversity (ShannonWeaver index in range of 1.3-2.3) and high values of equitability (Jaccard index in range of 0.6-0.9) throughout the core. Low diversity planktonic foraminiferal assemblages can be an index of palaeotemperature conditions because in modern oceans, the diversity of planktonic foraminifera is lower in cool than in warm waters (Boltovskoy \& Wright 1976).

In the HV-5 Rybníček core, low values of diversity are positively correlated with high relative abundance of cool water indicators (mainly Globorotalia and Globigerina) in the Globorotalia II. cluster (68-85\% of cool water indicators) and partly in the Globorotalia I. (42-88\%) and the Globorotalia-Globigerina cluster (the highest values do not exceed $75 \%$ ). High values are thought to be an expression of cool water conditions. Fluctuation of the relative abundance of cool water indicators along the core show an extreme increase in cool water indicators (relative abundance more than 70\%) between 167-141 m, 116-101 m and 66-69 $\mathrm{m}$ of the core depth.

Decrease in relative abundance of cool water foraminifera in assemblages of the Globigerinoides cluster, where values of the relative abundance of cool water indicators do not exceed 55\% (and in most of the samples do not exceed $30 \%$ ) and values of relative diversity of warm water indicators (mainly Globigerinoides) are in range of 44-83\%, signaling an increase in surface water temperatures. Along the core, increasing of warm water indicators (relative abundance more than $30 \%$ ) are obvious between 201-200 m, 133-126 m, 101-84 $\mathrm{m}$ and 74-70 m and at $113 \mathrm{~m}$ and $78 \mathrm{~m}$ of core depth.

Described changes in the relative abundance of cool and warm water indicators in the assemblages may indicate short-time climatic oscillations of cooler climate during the Miocene climatic optimum, which can be characterized as fairly uniform for the Badenian climate of the Central Paratethys realm (Böhme 2003, Doláková \& Slamková 2003).

These oscillations are also described in the Middle Miocene of the Central Paratethys by Bicchi et al. (2003), Holcová \& Zágoršek (2008) and Rupp \& Hohenegger (2008).

\section{Conclusions}

Foraminifera from seventy samples from the HV-5 Rybníček core were studied. The foraminiferal fauna were grouped into the seven clusters of benthic and four clusters of planktonic foraminifers with the goal of determining the palaeoenvironmental conditions of the Moravian middle part of the Carpathian Foredeep based on faunal parameters and palaeoecological indices.

The HV-5 Rybníček core can be well correlated with the Early Badenian time interval, characterized by the co-occurrence of the planktonic foraminiferal species Orbulina suturalis, Praeorbulina glomerosa circularis and Globigerinoides bisphericus with the lower part of the Upper Lagenid Zone.

In the clusters of benthic foraminifera, high occurrence of stress markers with the co-occurrence of oxiphylic species is common feature in all of the assemblages. The palaeoenvironment, where mixed sub-/dysoxic and oxiphylic species, was characterized by well-aerated bottom water with a redox boundary a few centimeters from the seafloor which was colonized by sub- and dysoxic foraminifers. Fluctuations between high oxic and suboxic oxygen content at the sea bottom is evident along the core and is depend on the nutrient content in photic zone. Eutrophization as a factor of fluctuations between high oxic and suboxic oxygen content at the sea floor is also 
documented by occurrence of small tests of planktonic foraminifera.

Palaeodepth conditions were estimated ranging from outer shelf to bathyal. But interpretation of the palaeodepth is complicated due to the high occurrence of high productivity indicators hence the estimated palaeodepth based on P/B-ratio, compared with depth ranges of benthic foraminifera, may be overestimated.

In clusters of planktonic foraminifera, cool/cool-temperate and warm/warm-temperate water indicators indicate temperature fluctuations along the HV-5 Rybníček core. Increasing cool/cool-temperate water indicators may indicate short-time climatic oscillations of cooler climate during the Miocene Climatic Optimum.

\section{Acknowledgments}

This contribution benefited from the financial support of the Czech Science Foundation, GAČR Project 205/09/0103: "Shallow water ecosystems from the Middle Miocene of the Central Paratethys: Succession and interactions between inorganic and organic elements of the ecosystems".

\section{References}

BÁLDI, K. 2006. Paleoceanography and climate of the Badenian (Middle Miocene, 16.4-13.0 Ma) in the Central Paratethys based on foraminifera and stable isotope $\left(\delta^{18} \mathrm{O}\right.$ and $\left.\delta^{13} \mathrm{C}\right)$ evidence. International Journal of Earth Sciences (Geologische Rundschau) 95, 119-142. DOI 10.1007/s00531-005-0019-9

Berggren, W.A., Kent, D.V., Swisher, C.C. \& Aubry, M.P. 1995. A revised Cenozoic geochronology and chronostratigraphy, 129-212. In Berrgren, W.A., Kent, D.V. \& Hardenbol, J. (eds) Geochronology, Time Scale and Global Stratigraphic Correlations: a Unified Temporal Framework for an Historical Geology. Society of Economic Paleontologists and Mineralogists, Special Publication 54.

Bicchi, M., Ferrero, E. \& Gonera, M. 2003. Palaeoclimatic interpretation based on Middle Miocene planktonic Foraminifera: the Silesia Basin (Paratethys) and Monferrato (Tethys) records. Palaeogeography, Palaeoclimatology, Palaeoecology 196, 265-303. DOI 10.1016/S0031-0182(03)00368-7

BöHme, M. 2003. The Miocene Climatic Optimum: evidence from exothermic vertebrates of Central Europe. Palaeogeography, Palaeoclimatology, Palaeoecology 31, 1-13. DOI 10.1016/S0031-0182(03)00367-5

Boltovskoy, E. \& Wright, R. 1976. Recent Foraminifera. 515 pp. Dr. W. Jung Publication, The Huage.

Brzobohatý, R. 1981. Paleoecology of the fossil Myctophids (Myctophidae, Teleostei). Západné Karpaty, séria Paleontológia 6 P, 31-38.

Brzobohatý, R. 1987. Contribution to the paleogeography of the Central Paratethys basins (Miocene) based on otolith fauna. Knihovnička ZPN, Miscellanea micropaleontologica II/2, 101-111.
Brzobohatý, R. 1997. Paleobathymetry of the Lower Badenian (Middle Miocene, Carpathian Foredeep, South Moravia) based on otholiths, 37-65. In HLAdilovÁ, Š. (ed.) Dynamika vztahů marinního a kontinetálního prostředí. Masarykova univerzita, Brno.

Burghardt, R. \& Molčíková, V. 1964. A new finding of the Tortonian tufface from the Carpathian Foredeep at Moravia. Zprávy Vlastivědného ústavu v Olomouci, Oddíl přirodovědný $131,8-12$.

Cicha, I. 2001. Outline of the stratigraphy of the Middle Miocene in the Alpine-Carpathian foredeep (Lower Austria, Moravia). Scripta Facultatis Scientiarum Naturalium Universitatis Masarykianae Brunensis, Geology 30, 23-26.

CíhA, I. \& C̆TYRoKÁ, J. 1995. Stratigraphical problems of the boundary members of the Karpatian and Early Badenian in the Southern Carpathian Foredeep. Zprávy o geologických výzkumech $v$ roce 1994, 20-21.

Cicha, I., Rögl, F., Rupp, C. \& ČтYrokÁ, J. (eds) 1998. Oligocene-Miocene Foraminifera of the Central Paratethys. 325 pp. Verlag Waldemar Kramer, Franfurkt am Main.

Den Dulk, M., Reichardt, G.J., Van Heyst, S., Zachariasse, W.J. \& ZwAAN, G.J. vAN DER 2000. Benthic Foraminifera as proxies of organic matter flux and bottom water oxygenation? A case history from the northern Arabian Sea. Palaeogeography, Palaeoclimatology, Palaeoecology 161, 337-359. DOI 10.1016/S0031-0182(00)00074-2

DolÁKovÁ, N. \& SlamkovÁ, M. 2003. Palynological characteristics of the Karpatian sediments, 325-345. In BRzовонAтÝ, R., Cicha, I., Kovéč, M. \& Rögl, F. (eds) The Karpatian - an Early Miocene stage of the Central Paratethys. Masaryk University, Brno.

GRILL, R. 1941. Stratigraphische Untersuchungen mit Hilfe von Mikrofaunen im Wiener Becken und den benachbarten Molasseanteilen. Öl und Kohle 37, 595-602.

Harzhauser, M. \& Piller, W.E. 2007. Benchmark data of a changing sea-paleogeography, paleobiography and events in the Central Paratethys during the Miocene. Palaeogeography, Palaeoclimatology, Palaeoecology 253, 8-31.

DOI 10.1016/j.palaeo.2007.03.031

Hinsbergen, D.J.J. van, Kouwenhoven, T.J. \& ZwaAn, G.J. van DER 2005. Paleobathymetry in the backstripping procedure: Correction for oxygenation effects on depth estimates. $P a$ laeogeography, Palaeoclimatology, Palaeoecology 221, 245-265. DOI 10.1016/j.palaeo.2005.02.013

HoHENEGGER, J. 2005. Estimation of environmental paleogradient values based on presence/absence data: a case study using benthic foraminifera for paleodepth estimation. Palaeogeography, Palaeoclimatology, Palaeoecology 217, 115-130. DOI 10.1016/j.palaeo.2004.11.020

Hohenegger, J., Ćorić, S., Khatun, H., Pervesler, P., Rögl, F., Rupp, C., Selge, A., Uchman, A. \& Wagreich, M. 2009. Cyclostratigraphic dating in the Lower Badenian (Middle Miocene) of the Vienna Basin (Austria): the Baden-Sooss core. International Journal of Earth Sciences (Geologische Rundschau) 98(4), 915-930. DOI 10.1007/s00531-007-0287-7

HolcovÁ, K. \& ZÁGORŠEK, K. 2008. Bryozoa, foraminifera and calcareous nannoplankton as environmental proxies of the "bryozoan event" in the Middle Miocene of the central Para- 
tethys (Czech Republic). Palaeogeography, Palaeoclimatology, Palaeoecology 267, 216-234.

DOI 10.1016/j.palaeo.2008.06.019

Jorissen, F.J., Destigter, H.C. \& Widmark, J.G.V. 1995. A conceptual model explaining benthic foraminifera microhabitat. Marine Micropaleontology 26, 3-15.

DOI 10.1016/0377-8398(95)00047-X

KAIHO, K. 1994. Benthic foraminiferal dissolved-oxygen index and dissolved-oxygen levels in the modern ocean. Geology 22, 719-722.

DOI 10.1130/0091-7613(1994)022<0719:BFDOIA >2.3.CO;2

KAIHO, K. 1999. Effect of organic carbon flux and dissolved oxygen on the benthic foraminiferal oxygen index (BFOI). $M a$ rine Micropaleontology 37, 67-76. DOI 10.1016/S0377-8398(99)00008-0

KopeCKÁ, J. 2009. Deep-water and shalow-water development of Lower Badenian in Middle Moravia. Geologické výzkumy na Moravě a ve Slezsku v roce 2008, 7-10.

KovÁč, M. 2000. Geodynamic, paleogeographic and structural development of the Carpathian-Pannonian Region during the Miocene. 202 pp. Veda, Bratislava.

Kováč, M., Andreyeva-Grigorovich, A., Bajraktarevic, Z., Brzobohatý, R., Filipescu, S., Fodor, L., Harzhauser, M., Nagymarosy, A., Oszczypko, N., Paveli, D., Rögl, F., SaFtic, B., Sliva, L. \& Studencka, B. 2007. Badenian evolution of the Central Paratethys Sea: paleogeography, climate and eustatic sea-level changes. Geologica Carpathica 58(6), 579-606.

MoLČíkovÁ, V. 1963. The Lower Tortonian microfauna from the Carpathian Foredeep. 134 pp. Geofond, Prague.

MARTINI, E. 1971. Standard Tertiary and Quaternary calcareous nannoplankton zonation. Proceeding of $2^{\text {nd }}$ Planktonic Conference, Roma 1970, 739-785.

Murray, J.W. 1991. Ecology and Palaeoecology of Benthic Foraminifera. 397 pp. Longman Scientific \& Technical, London.

Nehyba, S., Brzobohatý, R., Hladilová, Š. \& Doláková, N. 2000. Paleobathymetry of the Carpathian Foredeep in Moravia (Czech Republic) during the Lower Badenian. Biuletyn Panstwowego Instituta Geologicznego 387, 144-145.

Nehyba, S. \& Šikula, J. 2007. Depositional architecture, sequency stratigraphy and geodynamic development of the Carpathian Foredeep (Czech Republic). Geologica Carpathica 58(1), 53-69.

Papp, A. \& Turnovsky, K. 1953. Die Entwicklung der Uvigerinen im Vindobon (Helvet und Torton) des Wiener Beckens. Jahrbuch der Geologischen Bundesanstalt Wien 96, 117-142.

Papp, A., Cicha, I., Seneš, J. \& Steininger, F. 1978. Chronostratigraphie und Neostratotypen Miozän der Zentralen Paratethys, M4 Badenien. 594 pp. Veda, Bratislava.
Patterson, R.T., Fowler, A.D. \& Huber, B.T. 2004. Evidence of hierarchical organization in the planktic foraminiferal evolutionary record. The Journal of Foraminiferal Research 34, 85-95. DOI 10.2113/0340085

Piller, W.E., Harzhauser, M. \& Mandic, O. 2007. Miocene Central Paratethys stratigraphy - current status and future directions. Stratigraphy 4, 151-168.

Popov, S.V., Rögl, F., Rozanov, A.Y., Steininger, F.F., Shcherba, I.G. \& Kováč, M. 2004. Lithological-paleogeographic maps of Paratethys. Courier Forschungsinstitut Senckenberg 250, 1-46.

RöGL, F. 1986. Late Oligocene and Miocene planktonic foraminifera of the Central Paratethys, 315-328. In Boll, H.M., SAunders, J.B. \& Perch-Nielsen, K. (eds) Planktonic stratigraphy. Cambridge University Press, Cambridge.

RöGL, F. 1998. Paleogeographic consideration for Mediterranean and Paratethys seaways (Oligocene to Miocene). Annalen den Naturhistorische Museum Wien 99, 279-310.

RöGl, F. \& Steininger, F.F. 1983. Vom Zerfall der Tethys zu Mediterran und Paratethys. Die Neogene Paläogeographie und Palinspastik des zirkummediterranen Raumes. Annalen den Naturhistorische Museum Wien 85/A, 135-164.

Rögl, F., Spezafferri, S. \& Ćorić, S. 2002. Micropaleontology and biostratigraphy of the Karpatian-Badenian transition (Early-Middle Miocene boundary) in Austria (Central Paratethys). Courier Forschungsinstitut Senckenberg 237, 47-67.

RÖGL, F. \& SPEZZAFERRI, S. 2003. Foraminiferal paleoecology and biostratigraphy of the Mühlbach section (Gaindorf Formation, Lower Badenian), Lower Austria. Annalen den Naturhistorische Museum Wien 104A, 23-75.

Rupp, C. \& Hohenegger, J. 2008. Paloecology of planktonic foraminifera from the Baden-Sooss section (Middle Miocene, Badenian, Vienna Basin, Austria). Geologica Carpathica 59(5), 425-445.

Sen-Gupta, B.K. \& Machain-Castillo, M.L. 1993. Benthic foraminifera in oxygen-poor habitats. Marine Micropaleontology 20, 183-201. DOI 10.1016/0377-8398(93)90032-S

SpezzAFERri, S. \& Ćorić, S. 2001. Ecology of Karpatian (Early Miocene) foraminifera and calcareous nannoplankton from Laa an der Thaya, Lower Austria: a statistical approach. Geologica Carpathica 52, 361-374.

Spezzaferri, S., Ćorić, S., Hohenegger, J. \& Rögl, F. 2002. Basin-scale paleobiography and paleoecology: an example from Karpatian (Latest Burdigalian) benthic and planktonic foraminifera and calcareous nannofossils from the Central Paratethys. Geobios 35 (Supplement 1), 241-256.

DOI 10.1016/S0016-6995(02)00063-3

ZwaAn, G.J. van DER, JoRISSEN, F.J. \& DE STIGER, H.C. 1990. The depth dependency of planktonic/benthonic foraminiferal ratios: constraints and applications. Marine Geology 95, 1-16. DOI 10.1016/0025-3227(90)90016-D 